University of Denver

Digital Commons @ DU

Sturm College of Law: Faculty Scholarship

University of Denver Sturm College of Law

2018

Lost Profits in a Multicomponent World

Bernard Chao

Follow this and additional works at: https://digitalcommons.du.edu/law_facpub

Part of the Intellectual Property Law Commons 


\section{Lost Profits in a Multicomponent World}

\section{Publication Statement}

Published as 59 B.C. L. Rev. 1321 (2018). Copyright is held by the author. User is responsible for all copyright compliance. 


\section{LOST PROFITS IN A MULTICOMPONENT WORLD}

\section{BERNARD CHAO}

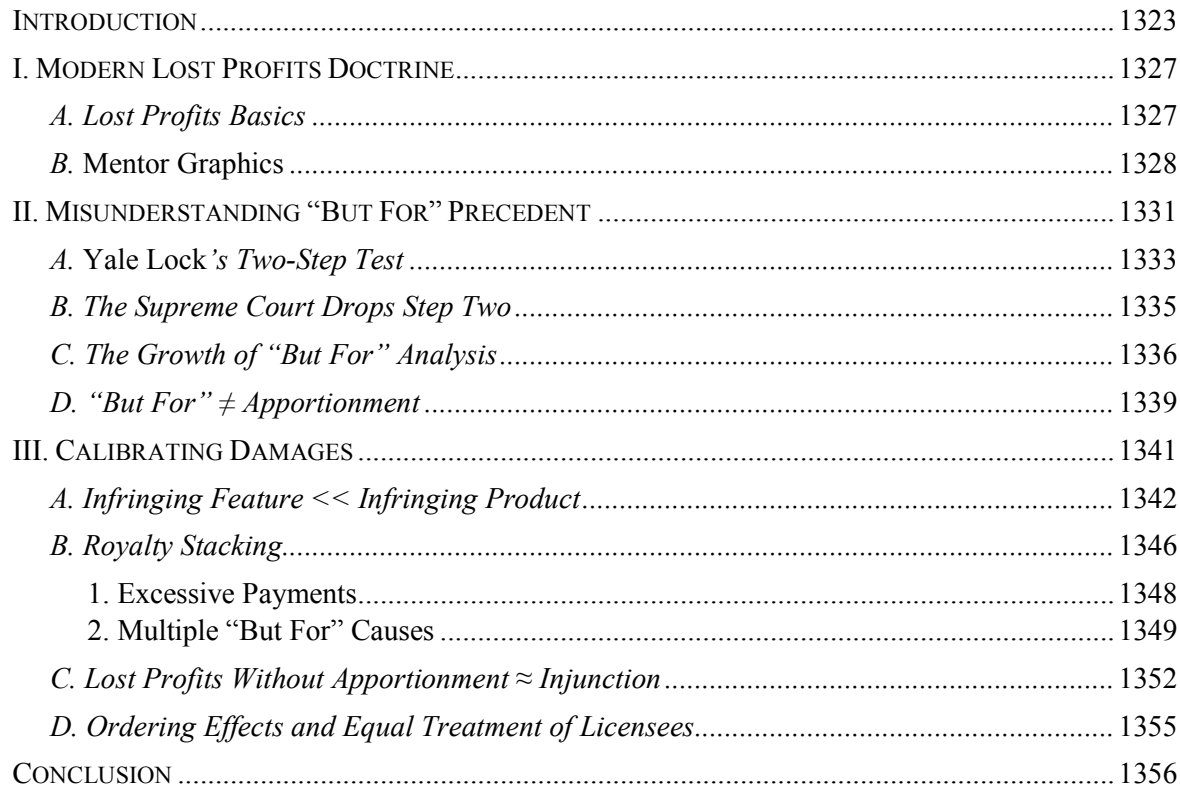




\title{
LOST PROFITS IN A MULTICOMPONENT WORLD
}

\author{
BERNARD CHAO*
}

\begin{abstract}
Given our adversarial system, it is not surprising that plaintiffs advance creative damages theories that would help them maximize their recoveries. In patent law, one recurring tactic for patentees is to seek remedies based on the entire infringing product instead of the specific feature covered by the patent. This distinction can significantly inflate remedies because modern multicomponent products contain thousands, sometimes hundreds of thousands, of different features. Thus, entire products are orders of magnitude larger, more complex, and more valuable than individual features.

In recent years, the Supreme Court has sensibly rejected attempts to base patent remedies on entire products in the context of permanent injunctions and design patents. The Federal Circuit nonetheless continues to allow patentees to recover all the lost profits associated with an entire infringing product even when the patent at issue only covers one aspect of a multicomponent product. In Mentor Graphics Corp. v. EVE-USA, Inc., the Federal Circuit recently affirmed a $\$ 36,417,661$ award, giving the patentee all of the lost profits caused by the sales of the defendant's infringing semiconductor emulator systems. The patent, however, covered only one feature of the defendant's product. The court explicitly rejected attempts to apportion profits between those attributable to the patented feature and other significant factors.

This Article argues that the failure to consider apportionment is wrong on both the law and policy. From a doctrinal perspective, the Federal Circuit has misinterpreted Supreme Court precedent, dating back to the nineteenth century, to arrive at an overly simplistic "but for" test to assess damages. From a policy perspective, awarding lost profits based on the entire infringing product - rather than just the feature - compensates the patentee for value she did not create and deters innovation in technologies that operate with or build upon other technology ("complementary technology"). Accordingly, this Article argues that it is time to realign the lost profits doctrine to make it consistent with other types of patent remedies. Patentees should only be compensated based on the value of the patent they hold. That means focusing the remedy on the infringing feature and not the infringing product.
\end{abstract}

(C) 2018, Bernard Chao. All rights reserved.

"Associate Professor, University of Denver Sturm College of Law. I would like to thank Jorge Contreras, Thomas Cotter, Dmitry Karshtedt, Amy Landers, Mark Lemley, Brian Love, Viva Moffat, Lucas Osborn, Justin Pidot and Melissa Wasserman for their helpful comments on various drafts of this Article. 


\section{INTRODUCTION}

In an adversarial legal system such as ours, parties are incentivized to seek the greatest possible recovery from a legal action. Therefore, it is not surprising that plaintiffs advance creative damages theories that would help them maximize their recoveries. In patent law, one recurring tactic for patentees is to seek remedies based on the entire infringing product instead of the specific feature covered by the patent. This distinction can significantly inflate remedies because modern multicomponent products contain thousands, sometimes hundreds of thousands, of different features. Entire products are orders of magnitude larger, more complex, and more valuable than their individual features. For example, a smartphone is far more than just the beveled shell that holds its electronics or the software that allows a user to unlock the phone with a single swipe (two separately patented features on Apple's iPhone). ${ }^{1}$ Numerous different innovations contribute to the success of multicomponent products, and awarding all of a product's lost profits based on one invention would crowd out returns for other important technologies that contribute to the success of these products.

In recent years, the United States Supreme Court has sensibly rejected attempts to base patent remedies on entire products in the contexts of both permanent injunctions and design patents. ${ }^{2}$ The United States Court of Appeals for the Federal Circuit nonetheless continues to allow patentees to recover all of the lost profits associated with an entire infringing product, even when the patent at issue only covers one aspect of that product. In 2017, in Mentor Graphics Corp. v. EVE-USA, Inc., the Federal Circuit affirmed a $\$ 36,417,661$ award, giving the patentee all of the lost profits caused by sales of the defendant's infringing semiconductor emulator systems. ${ }^{3}$ This decision explicitly rejected attempts to apportion profits between those attributable to the patented feature and other significant factors unrelated to the patented feature.

This Article argues that the failure to consider apportionment is wrong on both the law and policy. From a doctrinal perspective, the Federal Circuit has misinterpreted Supreme Court precedent, dating back to the nineteenth century, to arrive at an overly simplistic "but for" test to assess damages. From a policy perspective, awarding lost profits based on the entire infring-

${ }^{1}$ See U.S Patent No. 8,046,721 (issued Oct. 25, 2011) (swipe to unlock feature); U.S. Patent No. D618,677 (issued June 29, 2010) (phone shell). The patent for the later-developed slide to unlock feature was found invalid as obvious. See Apple Inc. v. Samsung Elecs. Co., 816 F.3d 788, 806 (Fed. Cir. 2016), reinstated in part, vacated in part, 839 F.3d 1034 (Fed. Cir. 2016).

${ }^{2}$ See, e.g., Samsung Elecs. Co. v. Apple Inc., 137 S. Ct. 429 (2016) (design patents); eBay Inc. v. MercExchange, L.L.C., 547 U.S. 388 (2006) (permanent injunctions).

${ }^{3} 851$ F.3d 1275, 1280 (Fed. Cir. 2017). 
ing product compensates the patentee for value that he or she did not create and deters innovation in complementary technology (i.e. technology that operates with other technology to create products). Accordingly, this Article argues that it is time to realign the lost profits doctrine to make it consistent with other types of patent remedies. Patentees should only be compensated based on the value of the patent that they hold. That means focusing the remedy on the infringing feature and not the infringing product.

The issue in Mentor Graphics is just the latest battleground in one of patent law's most fundamental debates. Some commentators think of patents as a kind of private property. ${ }^{4}$ The most straightforward implication of this view is that a prevailing patentee should be able to obtain a permanent injunction as a "matter of course." think of patent law as a type of policy lever, even seeing it as a kind of regulation. ${ }^{6}$ In this vein, both courts and commentators rely on patent law's goal of promoting innovation as their guiding principle. ${ }^{7}$ To the extent that

${ }^{4}$ See Richard A. Epstein, The Disintegration of Intellectual Property? A Classical Liberal Response to a Premature Obituary, 62 STAN. L. REV. 455, 461 (2010) ("The basic principles of property law are alive and well, and they are capable of reasonable extension to all forms of intellectual property."); see also Bernard Chao, Causation and Harm in a Multicomponent World, 164 U. PA. L. REV. ONLINE 61, 67-74 (2016) [hereinafter Chao, Causation and Harm], http://scholarship.law. upenn.edu/cgi/viewcontent.cgi?article $=1158 \&$ context=penn_law_review_online [https://perma. cc/6RRM-RUCA] (discussing how the Federal Circuit's view of patents as property contributed to the weakening of the "causal nexus" test for assessing irreparable harm); F. Scott Kieff, Property Rights and Property Rules for Commercializing Inventions, 85 MINN. L. REV. 697, 703 (2001) (noting that "the treatment of patents as property rights is necessary to facilitate investment in the complex, costly, and risky commercialization activities required to turn nascent inventions into new goods and services"); Adam Mossoff, Patents as Constitutional Private Property: The Historical Protection of Patents Under the Takings Clause, 87 B.U. L. REV. 689, 701 (2007) (noting that courts and Congress have historically classified "patents as property rights").

${ }^{5}$ See Epstein, supra note 4, at 489 ("In the patent context, this basic element of property theory has long been held 'to provide for an exclusive right to inventors to make, use and vend their inventions,' leading to the creation of a 'complete monopoly' for which injunctive relief is required as a matter of course.” (quoting Cont'l Paper Bag Co. v. E. Paper Bag Co., 210 U.S. 405, $423(1908))$ ).

${ }^{6}$ See Shubha Ghosh, Patents and the Regulatory State: Rethinking the Patent Bargain Metaphor After Eldred, 19 BERKELEY TECH. L.J. 1315, 1325 (2004) (asserting that patent law should be viewed as "economic regulation that overlaps with administrative law"); Mark A. Lemley, The Regulatory Turn in IP, 36 HARV. J.L. \& PUB. POL'Y 109, 110 (2013) (discussing how patent law could be viewed as both similar to property, as well as a "regulatory intervention" that limits property rights); Ted Sichelman, Purging Patent Law of "Private Law" Remedies, 92 TEX. L. REV. 517, 566 (2014) (proposing that "patent law remedies should be viewed . . . as part of a larger regulatory mechanism grounded in public law concepts"). One need not, however, accept the regulatory view of patent law to believe that innovation is its goal. After all, the Constitution speaks in terms of "promot[ing] the Progress of Science" when discussing patent rights. U.S. CONST. art. I, $\S 8$, cl. 8 .

${ }^{7}$ See, e.g., Bilski v. Kappos, 561 U.S. 593, 649 (2010) (Stevens, J., concurring) (expressing concerns about "stifl[ing] ... progress" of "scientific and technological work" when discussing 
inventors receive financial rewards, it is simply a byproduct of encouraging innovation. ${ }^{8}$ Advocates of the policy lever view worry that giving strong remedies for patents on a single feature will discourage complementary innovation; inventions that work with or build on the work of others. ${ }^{9}$ For example, two scholars criticized the prior rule of presumptively issuing permanent injunctions to prevailing patentees based on concerns about "patent holdup." ${ }^{10}$ In 2006, in eBay Inc. v. MercExchange, L.L.C., the Supreme Court changed that rule, holding that the courts must now weigh four equitable factors in determining whether to issue a permanent injunction. ${ }^{11}$ Although the result in $e B a y$ was clearly at odds with the property view of patents, the reasoning in Justice Thomas's majority opinion did not engage in this dispute. Rather, it relied on principles from other substantive areas of the law. ${ }^{12}$ This has allowed both property advocates and their opponents to continue their debate in other doctrinal areas of patent law, including lost profits.

Even though the Supreme Court has resolved the injunction issue and reduced the leverage that individual patented features have on entire products, the Federal Circuit continues to take a fundamentally different view when calculating lost profits. Given that the Federal Circuit has exclusive

patentable subject matter); Quanta Comput., Inc. v. LG Elecs., Inc., 553 U.S. 617, 626 (2008) (discussing the role of patents in "promot[ing] the progress of science and useful arts" in the context of patent exhaustion (quoting Motion Picture Patents Co. v. Universal Film Mfg. Co., 243 U.S. 502, 511 (1917))); Graham v. John Deere Co., 383 U.S. 1, 9 (1966) (noting that patent law's purpose was "to bring forth new knowledge"); WILLIAM M. LANDES \& RICHARD A. POSNER, THE ECONOMIC STRUCTURE OF INTELLECTUAL PROPERTY LAW 294 (2003) ("The standard rationale of patent law is that it is an efficient method of enabling the benefits of research and development to be internalized, thus promoting innovation and technological progress.").

${ }^{8}$ See Motion Picture, 243 U.S. at 511 ("[T]his court has consistently held that the primary purpose of our patent laws is not the creation of private fortunes for the owners of patents but is 'to promote the progress of science and useful arts' ....") quoting U.S. CONST. art. I, § 8)).

${ }^{9}$ See, e.g., Mark A. Lemley, The Economics of Improvement in Intellectual Property Law, 75 TEX. L. REV. 989, 1067 (1997) (asserting that if those who wish to improve upon an invention are forced to pay high prices to license the original invention, an "underproduction of improvements" will result); Robert P. Merges \& Richard R. Nelson, On the Complex Economics of Patent Scope, 90 COLUM. L. REV. 839, 843-44 (1990) ("Without extensively reducing the pioneer's incentives, the law should attempt at the margin to favor a competitive environment for improvements, rather than an environment dominated by the pioneer firm."); Suzanne Scotchmer, Standing on the Shoulders of Giants: Cumulative Research and the Patent Law, J. ECON. PERSP., Winter 1991, at 29, 32 (explaining how giving original inventors broad patent protection "can lead to deficient incentives to develop second generation products").

${ }^{10}$ See Mark A. Lemley \& Carl Shapiro, Patent Holdup and Royalty Stacking, 85 TEX. L. REV. 1991, 2008-10 (2007) (explaining how granting an injunction for infringement of single feature can give the patentee disproportionate bargaining power).

${ }_{11}$ eBay, 547 U.S. at 388.

${ }^{12}$ See id. at 391-92 (citing the "well-established principles of equity" and the right to exclude under property law). 
appellate jurisdiction over patent law, this inconsistency is particularly troublesome. In Mentor Graphics, the court relied solely on "but for" analysis and awarded lost profits based on the entire infringing product. ${ }^{13}$ If a patentee cannot obtain an injunction against a single feature because the injunction can be used to holdup an entire product, recovering all of the lost profits caused by the infringing product should also not be allowed. In sum, the Federal Circuit's approach to lost profits is clearly at tension with the Supreme Court's decision on injunctions. Moreover, sound policy weighs in favor of reducing the leverage that patents on individual features, even important features, can exert. Otherwise, owners of these patents will be able to effectively control products that were created by a community of different inventors. The solution is to apportion lost profits based on the relative contribution of the patented feature.

Part I of this Article reviews the basics of modern patent lost profits law. ${ }^{14}$ Relying on the facts of Mentor Graphics, it then explains why the current test calculates lost profits based on an entire infringing product without considering what portion of those profits are actually attributable to the infringing feature. ${ }^{15}$ In other words, when calculating lost profits, patent law does not apportion. Part II takes a step back into history and explains why the modern view of lost profits is actually based on a misinterpretation of two longstanding Supreme Court cases, Yale Lock Manufacturing Co. v. Sargent and Aro Manufacturing Co. v. Convertible Top Replacement Co. ${ }^{16}$ Part II then returns to the present to critically examine the Federal Circuit's futile attempts to reconcile the Supreme Court's historical apportionment requirement with the Mentor Graphics decision's refusal to consider the value that other factors contributed to the infringing product. ${ }^{17}$

Part III analyzes the issue of apportionment and lost profits from a policy perspective. ${ }^{18}$ It describes both eBay and Samsung Electronics Co. v. Apple Inc. and explains why the Supreme Court refused to allow injunctions and design patent damages to be based on an entire product in these cases. Part III then discusses further policy concerns, including issues of royalty stacking, multiple "but for" causes, and basic fairness. ${ }^{19}$

${ }^{13}$ Mentor Graphics, 851 F.3d at 1290.

${ }^{14}$ See infra notes $20-59$ and accompanying text.

${ }^{15}$ See infra notes 42-59 and accompanying text.

${ }^{16}$ Aro Mfg. Co. v. Convertible Top Replacement Co., 377 U.S. 476, 507 (1964); Yale Lock Mfg. Co. v. Sargent, 117 U.S. 536, 549-51 (1886); see infra notes 60-125 and accompanying text.

${ }^{17}$ Mentor Graphics, 851 F.3d at 1280; see infra notes 103-125 and accompanying text.

${ }^{18}$ See infra notes $126-195$ and accompanying text.

${ }^{19}$ Samsung, 137 S. Ct. at 433; eBay, 547 U.S. at 388; see infra notes 161-195 and accompanying text. 


\section{MODERN LOST PROFITS DOCTRINE}

\section{A. Lost Profits Basics}

The statute governing compensation for patent infringement, 35 U.S.C. $\S 284$, states: "Upon finding for the claimant the court shall award the claimant damages adequate to compensate for the infringement, but in no event less than a reasonable royalty for the use made of the invention by the infringer ...." ${ }^{20}$ Lost profits are generally sought when the infringer's products compete with the patentee's products. ${ }^{21}$ The lost profits remedy seeks to restore the patent holder to the financial condition that it would have occupied had there been no infringement. ${ }^{22}$ Reasonable royalties, on the other hand, are the minimum damages for those patentees who do not meet the requirements of lost profits. ${ }^{23}$ It is significantly more difficult to establish lost profits than reasonable royalties. ${ }^{24}$ Importantly, the recovery of lost profits does not have a punitive aspect. ${ }^{25}$ Other types of damages can be imposed for misconduct. ${ }^{26}$

Probably the most well-known modern decision on lost profits is Panduit Corp. v. Stahlin Bros. Fibre Works, decided by the Sixth Circuit in 1978. ${ }^{27}$ Later in this Article, I will discuss this case in more depth. ${ }^{28}$ For now, it is sufficient to understand that Panduit requires patentees to prove four elements to recover lost profits. The patentee must show: "(1) demand for the patented product, (2) absence of acceptable noninfringing substi-

\footnotetext{
${ }^{20} 35$ U.S.C. $\S 284$ (2012).

${ }^{21}$ See, e.g., Mentor Graphics, 851 F.3d at 1280.

${ }^{22}$ Panduit Corp. v. Stahlin Bros. Fibre Works, 575 F.2d 1152, 1156 (6th Cir. 1978).

${ }^{23}$ Zelin Yang, Damaging Royalties: An Overview of Reasonable Royalty Damages, 29 BERKELEY TECH. L.J. 647, 649 (2014).

${ }^{24}$ See Mark A. Lemley, Distinguishing Lost Profits from Reasonable Royalties, 51 WM. \& MARY L. REV. 655, 657-58 (2009) (noting the difficulty of establishing lost profits); Yang, supra note 23 (noting that those who cannot meet the standard for lost profits can get reasonable royalties). To establish lost profits, patentees must show that they would have been capable of profiting from the patent under the Panduit factors discussed below. See infra notes 27-31 and accompanying text. Patentees seeking reasonable royalties are those unable to establish lost profits. Yang, supra note 23 , at 650 . The amount of reasonable royalties that such patentees receive is the market price for the licensing fee that the infringer would have paid the patentee to use the patent. $I d$. at 651.

${ }^{25}$ See Pall Corp. v. Micron Separations, Inc., 66 F.3d 1211, 1223 (Fed. Cir. 1995) (stating that "the purpose of compensatory damages is not to punish the infringer, but to make the patentee whole").

${ }^{26}$ See Halo Elecs., Inc. v. Pulse Elecs., Inc., 136 S. Ct. 1923, 1932 (2016) (describing the standard for recovering enhanced damages for "egregious" infringement behavior); Octane Fitness, LLC v. Icon Health \& Fitness, Inc., 134 S. Ct. 1749, 1756-57 (2014) (discussing the recovery of attorney's fees in exceptional cases).

${ }^{27}$ Panduit, 575 F.2d at 1156.

${ }^{28}$ See infra notes $97-102$ and accompanying text.
} 
tutes, (3) his manufacturing and marketing capability to exploit the demand, and (4) the amount of the profit he would have made." ${ }^{29}$ Each of these factors is intended to ensure that the patentee only receives damages for profits that it would have earned "but for" the infringement. ${ }^{30}$ For example, under the first factor, the patentee should not be able to recover lost profits unless the infringer's customers would have demanded the patentee's products in the absence of infringement. Similarly, under the second factor, lost profits are unavailable if the infringer's customers would have chosen a legitimate, or non-infringing, third party supplier's products instead of the patentee's products. The third factor ensures that the patentee had the ability to supply any customers that would have purchased its products in the absence of infringement. The fourth factor insists that profits be calculated based on the financial circumstances that would have existed but for the infringement. In other words, the lost profits calculation must account for how the market would have looked without the infringer. For example, the patentee might have incurred increased costs to supply more products. Or, it may have enjoyed supra-competitive profits because the infringer was kept out of the market. In short, the four so-called Panduit factors use the same kind of "but for" causation analysis used in tort law. ${ }^{31}$

\section{B. Mentor Graphics}

The Federal Circuit issued its opinion in Mentor Graphics in 2017. ${ }^{32}$ In one respect, it looks like an easy application of the Panduit factors because "but for" the defendant Synopsys' infringement, the plaintiff Mentor Graphics would have captured Synopsys' sales. Mentor Graphics and Synopsys (the company that acquired EVE-USA), both made emulation and verification systems. These systems are incredibly complicated and expensive. They are used to test semiconductor chip designs that contain up to two billion circuits. ${ }^{33}$ The profits on a single unit can exceed one million dollars. $^{34}$

${ }^{29}$ Panduit, 575 F.2d at 1156.

${ }^{30} \mathrm{See} i d$. (stating that a patent owner must prove the four factors in order to receive damages for "the profits on sales he would have made absent the infringement").

${ }^{31}$ See RestateMENT (THIRD) OF TORTS $§ 26$ (AM. LAW. INST. 2000) (defining factual case of harm as occurring "when the harm would not have occurred absent the conduct").

${ }^{32}$ Mentor Graphics, 851 F.3d at 1275.

${ }^{33}$ See MENTOR GRAPHICS, ANNUAL REPORT 4 (2016), http://s3.mentor.com/investor-relations/ FY16-annual-report.PDF [https://perma.cc/667W-5U55].

${ }^{34}$ See Transcript of Record for October 9, 2014 at 1918, Mentor Graphics Corp. v. EVE-USA, Inc., 2015 U.S. Dist. LEXIS 29720 (D. Or. Mar. 11, 2015) (Nos. 3:10-cv-954-MO, 3:12-cv-1500MO, 3:13-cv-579-MO) [hereinafter October 9, 2014 Transcript] (asserting, on behalf of Mentor Graphics, in its closing statement that the profit on the sale of a single unit was $\$ 1,121,000$ ). 
Mentor Graphics and Synopsys were embroiled in a large patent war, with each side alleging that the other party infringed its patents. ${ }^{35}$ In the end, only one patent made its way to the jury, a Mentor Graphics patent. ${ }^{36}$ That patent, U.S. Patent No. 6,240,376 ("the '376 patent"), was entitled "Method and Apparatus for Gate-Level Simulation of Synthesized Register Transfer Level Designs with Source-Level Debugging." 37 It covered technology that allowed an emulator to obtain more information about the circuit by inserting "test probes" at certain points in the software. ${ }^{38}$ These probes in turn gave the emulator the ability to measure "intermediate values." ${ }^{39}$ This additional information allowed chip designers to debug chip designs faster and more accurately. ${ }^{40}$ Mentor Graphics alleged that Synopsys' $\mathrm{ZeBu}$ emulators used this technology and infringed the ' 376 patent. $^{41}$

In the damages portion of the trial, Mentor Graphics argued that "but for" the sale of forty-five of Synopsys' infringing $\mathrm{ZeBu}$ emulators, customers would have purchased Mentor Graphics' Veloce emulators instead. ${ }^{42}$ Accordingly, Mentor Graphics asked for all of the profits that these potential sales would have generated..$^{43}$ In response, Synopsys attempted to argue that any lost profits should be apportioned based on the relative contribution of the infringing feature. ${ }^{44}$ Indeed, focusing only on debugging, the Zebu emulators had many other important features, including: dynamic probes, static probes, flexible probes, memory access, and triggers. ${ }^{45}$ The trial court, however, did not permit Synopsys to offer evidence of the value that any of these other features contributed to the infringing $\mathrm{ZeBu}$ emulators. ${ }^{46}$ At trial, Mentor Graphics prevailed. The jury found that Synopsys infringed the ' 376 patent and awarded Mentor Graphics $\$ 36,417,661$ in lost profits. ${ }^{47}$

${ }^{35}$ Mentor Graphics, 851 F.3d at 1280-81.

${ }^{36} I d$. at 1280 . The trial court granted summary judgments on the other patents finding that they were either invalid for various different reasons or that the infringement claims were barred. Id.

${ }^{37}$ U.S. Patent No. 6,240,376.

${ }^{38}$ Mentor Graphics, 851 F.3d at 1281.

${ }^{39} \mathrm{Id}$.

${ }^{40}$ See id.

${ }^{41} I d$. at 1282 .

${ }^{42}$ Id. at 1283; October 9, 2014 Transcript, supra note 34, at 1914.

${ }^{43}$ Mentor Graphics, 851 F.3d at 1283.

${ }^{44} \mathrm{Id}$.

${ }^{45}$ See Transcript of Record for October 6, 2014 at 1303, Mentor Graphics, 2015 U.S. Dist. LEXIS 29720 (Nos. 3:10-cv-954-MO, 3:12-cv-1500-MO, 3:13-cv-579-MO).

${ }^{46}$ Transcript of Record for October 8, 2014 at 1649, Mentor Graphics, 2015 U.S. Dist. LEXIS 29720 (Nos. 3:10-cv-954-MO, 3:12-cv-1500-MO, 3:13-cv-579-MO); see infra notes 158-159 and accompanying text.

${ }^{47}$ Mentor Graphics, 851 F.3d at 1283. Mentor Graphics asked for $\$ 47,191,819$. October 9, 2014 Transcript, supra note 34, at 1920. 
As the Federal Circuit noted, the facts in this case allowed for a "remarkably simple" application of the Panduit factors. ${ }^{48}$ The lost profits at issue concerned sales that Synopsys made to Intel. ${ }^{49}$ Mentor Graphics successfully argued that it would have sold its emulators to Intel if Synopsys' emulators did not include two features covered by the ' 376 patent. ${ }^{50}$ For the purposes of appeal, Synopsys accepted those arguments as true. ${ }^{51}$ Synopsys also did not challenge a finding that there were no non-infringing alternatives. ${ }^{52}$ Thus, a straightforward application of the Panduit factors led to an award encompassing all of the profits that Mentor Graphics would have made had it sold its emulators to Intel instead of Synopsys.

Rather than challenging the factual findings, Synopsys argued that the trial court should have instructed the jury to discount any lost profits by only taking into account the relative contribution that the patented invention made to the entire product. ${ }^{53}$ This principle, known as apportionment, is already part of the reasonable royalty calculation. ${ }^{54}$ Although there is a historical basis for also apportioning lost profits, that has not been a part of modern patent law. ${ }^{55}$ Mentor Graphics did acknowledge this precedent in name, but it ignored the substance of what apportionment requires. ${ }^{56} \mathrm{In}$ stead, Mentor Graphics said that the patentee was entitled to be "made whole." ${ }^{57}$ Under this view, the fact finder does not need to consider which lost profits should be attributed to the infringing feature and which should be attributed to other factors.

In an intuitive sense, the Federal Circuit is absolutely correct. The only way to restore Mentor Graphics to the position that it would have held had Synopsys not sold any infringing products was to award Mentor Graphics all of its lost profits without apportionment.

The problem with this kind of "but for" analysis, however, is that it improperly confuses harm caused by an infringing product with harm

${ }^{48}$ See Mentor Graphics, 851 F.3d at 1286.

${ }^{49} \mathrm{Id}$.

${ }^{50} \mathrm{Id}$.

${ }^{51} \mathrm{Id}$. at $1286-87$.

${ }^{52} \mathrm{Id}$. at 1287.

${ }^{53} \mathrm{Id}$.

${ }^{54}$ See Ericsson, Inc. v. D-Link Sys., Inc., 773 F.3d 1201, 1226 (Fed. Cir. 2014) (“[W]here multi-component products are involved, the governing rule is that the ultimate combination of royalty base and royalty rate must reflect the value attributable to the infringing features of the product, and no more."); VirnetX, Inc. v. Cisco Sys., Inc., 767 F.3d 1308, 1326 (Fed. Cir. 2014) ("No matter what the form of the royalty, a patentee must take care to seek only those damages attributable to the infringing features.").

${ }^{55}$ See infra notes 60-72 and accompanying text.

${ }^{56}$ Mentor Graphics, 851 F.3d at 1283 n.3.

${ }^{57}$ Id. at 1290 . 
caused by an infringing feature. Patent remedies should focus on the infringing feature, and the only way to properly determine the damages associated with that harm is to apply apportionment principles. Mentor Graphics, nonetheless, does not stand alone. Modern lower court decisions have similarly refused to apply apportionment to lost profits. ${ }^{58}$ Part II of this Article explains how this view stems from a mistaken understanding of Supreme Court precedent dating back to the nineteenth century. ${ }^{59}$

\section{Misunderstanding “But FoR” PRECEDENT}

Even though apportioning lost profits has deep historical roots, modern cases like Mentor Graphics Corp. v. EVE-USA, Inc., Inc. have generally rejected that concept. ${ }^{60}$ One scholar has provided a thorough account of the history of apportioning lost profits. ${ }^{61} \mathrm{He}$ explained that "[b]etween 1854 and 1915, the Supreme Court decided more than two dozen significant patent damages cases and in each, adhered to the rule that a patentee must satisfy the apportion requirement to recover for infringement." ${ }^{22}$ Many of these cases dealt with the remedy of restitution. ${ }^{63}$ Restitution allowed a patent holder to capture the infringer's profits as opposed to awarding to the patentee profits it would have made absent any infringement (lost profits). Restitution was essentially eliminated by a 1946 amendment to the patent laws. ${ }^{64}$ This development should not have affected the applicability of apportionment to lost profits calculations. After all, a few of the earlier deci-

${ }^{58}$ See infra notes 66-72 and accompanying text.

${ }^{59}$ See infra notes $60-125$ and accompanying text.

${ }^{60}$ See supra notes 56-57 and accompanying text.

${ }^{61}$ Eric Bensen, Apportioning of Lost Profits for Patent Infringement, LEXISNEXIS EMERGING ISSUES ANALYSIS (Apr. 2017), http://www.ericbensen.com/Resources/48.\%20Apportionment\% 20of\%20Lost $\% 20$ Profit $\% 20$ for $\% 20$ Patent\%20Infringement.pdf $\quad$ [https://perma.cc/X4BM-HP2F] [hereinafter Bensen, Patent Infringement]; Eric E. Bensen, Apportionment of Lost Profits in Contemporary Patent Damages Cases, 10 VA. J.L. \& TECH., Summer 2005, at 1, 23-45, http://vjolt. org/wp-content/uploads/2017/Articles/vol10/issue3/v10i3_a8-Bensen.pdf [https://perma.cc/8CXJLZBJ] [hereinafter Bensen, Patent Damages Cases].

${ }^{62}$ Bensen, Patent Infringement, supra note 61, at 3 (citing Bensen, Patent Damages Cases, supra note 61, at 29-42).

${ }^{63}$ See, e.g., Dowagiac Mfg. Co. v. Minn. Moline Plow Co., 235 U.S. 641, 648 (1915) (“As the exclusive right conferred by the patent was property and the infringement was a tortious taking of a part of that property, the normal measure of damages was the value of what was taken.").

${ }^{64}$ See Act of Aug. 1, 1946, Pub. L. No. 587, 60 Stat. 778, 778 (1946) (codified as 35 U.S.C. $\S 70$ and subsumed into 35 U.S.C. $\$ 285$ ) (stating that "for [patent] infringement the complainant shall be entitled to recover general damages which shall be due compensation for making, using, or selling the invention, not less than a reasonable royalty"); John M. Golden \& Karen E. Sandrik, A Restitution Perspective on Reasonable Royalties, 36 REV. LITIG. 335, 344 (2017) (explaining how the 1946 statute ended restitution as a remedy for utility patents). 
sions concerned lost profits. ${ }^{65}$ Moreover, the concept of apportionment is equally suitable for recovering lost profits as it is to restitution. No matter how the patent holder is compensated, apportionment acknowledges that other factors beyond the patent at issue drive value.

Modern courts have nonetheless paid little attention to this precedent. The explanations for rejecting it differ. One district court wrongly said that apportionment only applied to restitution. ${ }^{66}$ Several recent district court decisions have relied on the absence of modern authority supporting apportionment. ${ }^{67}$ In Mentor Graphics, the Federal Circuit temporarily relied on yet another rationale before revising its view. The original panel's decision in Mentor Graphics conceded that apportionment applied to all types of patent damage recoveries, but argued that the Panduit factors somehow incorporated apportionment principles. ${ }^{68}$ Perhaps understanding that there was no basis for this conclusion, an en banc opinion (denying rehearing) relied on a wholly different basis. ${ }^{69}$ Rather than endorsing the idea that the Panduit analysis applied apportionment principles, the en banc opinion said that meeting the Panduit factors satisfied the entire market value rule, making apportionment unnecessary. ${ }^{70}$ Although some commentators have advocated for apportionment, others have agreed with how courts have recently viewed the lost profits doctrine. ${ }^{71}$

Regardless of how they arrived at the test, modern decisions now say that the sole test for determining lost profits is a simple "but for" analysis,

${ }^{65}$ See Bensen, Patent Infringement, supra note 61, at 3 (explaining how some of the leading apportionment cases involved the recovery of lost profits); see also Garretson v. Clark, 111 U.S. 120,121 (1884) (stating that patentees must apportion both "the defendant's profits and the patentee's damages between the patented feature and the unpatented features").

${ }^{66}$ See W.L. Gore \& Assocs. v. Carlisle Corp., 198 U.S.P.Q 353, 363-64 (D. Del. 1978).

${ }^{67}$ See Brocade Commc'ns Sys., Inc. v. A10 Networks, Inc., No. C 10-3428 PSG, 2013 WL 10601009 , at $* 2$ (N.D. Cal. May 15, 2013) (asserting that although the concept of apportionment was "appealing," the defendant's argument "has not cited any Supreme Court or Federal Circuit case requiring an apportionment when a patentee claims lost profits based on Panduit"). The court further stated, "Nor do any of the cases it does cite arise in the context of a Panduit-based lost profits claim." Id.; see also Universal Elecs., Inc. v. Universal Remote Control, Inc., No. SACV 12-00329 AG (JPRx), 2014 WL 12586737, at *6 (C.D. Cal. Apr. 21, 2014).

${ }^{68}$ Mentor Graphics Corp. v. EVE-USA, Inc., 851 F.3d 1275, 1287-88 (Fed. Cir. 2017).

${ }^{69}$ See Mentor Graphics Corp. v. EVE-USA, Inc. (Mentor Graphics II), 870 F.3d 1298, 1300 (Fed. Cir. 2017).

${ }^{70} \mathrm{Id}$.

${ }^{71}$ See, e.g., Roger D. Blair \& Thomas F. Cotter, Rethinking Patent Damages, TEX. INTELL. PROP. L.J., Fall 2001, at 1, 28 (2001) (suggesting that there is no need to apportion lost profits); Brent Rabowsky, Recovery of Lost Profits on Unpatented Products in Patent Infringement Cases, 70 S. CAL. L. REV. 281, 295 (1996) ("[A]pplication of the entire market value rule and the generic 'but for' causation test eliminates the need for apportionment."). 
and they use that framework to reject apportionment. ${ }^{72}$ "But for" analysis and apportionment, however, are really two steps in a more comprehensive approach to lost profits. Ironically, the foundation for the current singleminded focus on "but for" analysis is the 1886 Supreme Court decision of Yale Lock Manufacturing Co. v. Sargent that illustrates the two-step approach. $^{73}$

Although the Supreme Court applied "but for" analysis in Yale Lock, it also recognized that many factors beyond the patented invention caused a patent holder to lose profits, and it apportioned lost profits accordingly. ${ }^{74}$ That message has been lost, as courts today have focused exclusively on Yale Lock's "but for" causation language. ${ }^{75}$ The result is that modern lost profits doctrine fails to recognize the difference between an infringing feature and an infringing product, and thus overcompensates patent holders. A proper appreciation of this Supreme Court decision, however, can help restore apportionment to its proper role.

\section{A. Yale Lock's Two-Step Test}

The patent at issue in Yale Lock covered the use of a particular kind of "turning-bolt" for use in a combination lock. ${ }^{76}$ The defendant's sale of infringing locks forced the patent holder to sell its own products at a lower price - one dollar less for one lock and two dollars less for another lock. ${ }^{77}$ Modern terminology would classify this as a patent holder losing profits due to price erosion. ${ }^{78}$ The Supreme Court explained that lost profits must be calculated by examining the "difference between [the patent holder's] pecuniary condition after the infringement, and what his condition would have been if the infringement had not occurred."79 This is the well-known "but for" analysis language that later cases would repeatedly quote. Im-

${ }^{72}$ See Bensen, Patent Damages Cases, supra note 61, at 22-23 (commenting that courts have "reduc[ed] a claim for lost profits to a simple 'but for' test, thereby allowing a patentee to recover its entire lost profit on a lost sale regardless of the contribution of the patent to those profits").

${ }^{73}$ Yale Lock Mfg. Co. v. Sargent, 117 U.S. 536, 549-51 (1886); see infra notes 86-96 and accompanying text (describing later courts' interpretations of Yale Lock).

${ }^{74}$ Yale Lock, 117 U.S. at 549-51.

${ }^{75}$ See, e.g., Aro Mfg. Co. v. Convertible Top Replacement Co., 377 U.S. 476, 507 (1964).

${ }^{76}$ Yale Lock, 117 U.S. at 542.

${ }^{77} \mathrm{Id}$. at 548. Interestingly, although the underlying master's decision found that the infringer's sales had caused the patent holder to lose sales too, no lost profits were awarded for these lost sales. Id. at 549 .

${ }^{78}$ See McSherry Mfg. Co. v. Dowagiac Mfg. Co., 163 F. 34, 35 (6th Cir. 1908) ("The damages claimed were on account of reduction of prices, the right to recover which stands on exactly the same ground as damages on account of lost sales."). Although the typical lost profits case deals with lost sales and not price erosion, this distinction does not affect the analysis.

${ }^{79}$ Yale Lock, 117 U.S. at 552. 
portantly, the "but for" analysis is only the first step in Yale Lock's damages determination. This step calculates the profits lost due to the sale of the infringing products - here, the infringing combination locks. It does not, however, attempt to determine what profits were lost because of the infringing feature - here, the turning bolt. That determination occurs in the second step of Yale Lock's analysis.

Yale Lock did not simply award the patent holder all of the profits it lost because of the sale of the infringing products. Instead, the Supreme Court affirmed the underlying decision and reduced the patent holder's lost profits by fifty percent because of "other causes which gave to the defendant an advantage in selling its locks." 80 Those other causes included third party patented technology found in the infringing lock, other "superior external attractions" found in the infringing lock, the "shape" of the infringing locks' cases, and "commercial success" that the defendant was having in sales. ${ }^{81}$ Thus, the second step in Yale Lock's analysis is apportioning the lost profits between the profits lost due to the patented invention, and those attributed to other factors. ${ }^{82}$ Importantly, this second step did not just apply to minor infringing features. The infringing turning bolt in Yale Lock was found to be an "essential feature of the infringing locks," and the Supreme Court characterized the infringement as causing the patent holder's "entire loss." 83

In sum, in Yale Lock, the Supreme Court applied a two-step analysis. In the first step, it used "but for" analysis to determine all of the lost profits attributable to the infringing product. Recognizing that the infringing feature was only part of the infringing product, the Court then proceeded to a second step. The Court apportioned lost profits between the patented feature and other contributions made by the infringer. Importantly, the Supreme Court did not just look at the product's patented features when applying apportionment. It also considered other factors that may have contributed to the infringer's profits. Yale Lock even used the modern term "apportionment" when describing the concept. ${ }^{84}$ Of course, because of the second step,

${ }^{80} \mathrm{Id}$.

${ }^{81} I d$. at 549-50. In modern terms, the latter factor could consist of defendant's brand recognition or superior marketing or manufacturing abilities.

${ }^{82}$ In Yale Lock, the split between the invention and other factors was 50/50, and there was no indication that the numbers were derived from anything other than a crude estimate.

${ }^{83}$ Yale Lock, 117 U.S. at 551-52.

${ }^{84} \mathrm{Id}$. at 550 . 
the patent holder only recovered the portion of lost profits attributable to the infringing feature, differentiating Yale Lock from modern patent law. ${ }^{85}$

\section{B. The Supreme Court Drops Step Two}

The reason that the modern day understanding of Yale Lock stops with step one can be traced to the cursory analysis of calculating damages that the Supreme Court provided in 1964, in Aro Manufacturing Co. v. Convertible Top Replacement $\mathrm{Co}^{86}$ This mistake is somewhat understandable, given that the Court was focused on a different issue. The relevant part in Aro focused on explaining what damages one responsible party (the contributory infringer) must pay when money has already been paid to the patent holder on behalf of another responsible party (the direct infringer) ${ }^{87}$

A more detailed examination of Aro helps explain the misunderstanding. The plaintiff Convertible Top's patent covered a "top-structure for automobile convertibles." ${ }^{88}$ The defendant Aro "produce[d] fabric components designed as replacements for worn-out fabric portions of convertible tops." ${ }^{89}$ The primary issue on appeal was the level of knowledge that Convertible Top had to prove to make out a case of contributory infringement under 35 U.S.C. $\S 271$ (c).$^{90}$ The Supreme Court held that there must be a showing that Aro not only knew of the patent, but also that the use of the component would infringe the patent. ${ }^{91}$

For our purposes, the important discussion in Aro dealt with damages. Even though neither party briefed or argued damages, the Supreme Court felt compelled to address what it believed to be a faulty assumption made by the parties. ${ }^{92}$ Specifically, the Court went out of its way to point out that if earlier payments made on behalf of the direct infringers (customers who purchased Ford automobiles) fully compensated the patentee for the infringement, then Aro would owe nothing for contributing to the customers' infringement. ${ }^{93}$ Before reaching that conclusion, however, the Court dis-

${ }^{85}$ See Dan L. Burk \& Mark A. Lemley, The Patent Crisis and How the Courts Can SOLVE IT 53 (2009) (noting that much of patent law, including lost profits jurisprudence, assumes that a single patent covers a single product).

${ }^{86}$ Aro, 377 U.S. at 502.

${ }^{87} \mathrm{Id}$. at $512-13$.

${ }^{88} I d$. at 478 .

${ }^{89} I d$. at 479 .

${ }^{90} \mathrm{Id}$. at 481 .

${ }^{91} I d$. at 491 .

${ }^{92} I d$. at 502.

${ }^{93}$ Id. at 512. Earlier, Ford had made payments on behalf of customers who purchased Ford automobiles. $I d$. at 493-94. Aro was contributing to these customers' direct infringement by selling them replacement parts for their convertible tops. $I d$. 
cussed what full compensation for patent infringement meant. Relying on the oft quoted passage from Yale Lock, the Supreme Court explained that patent damages restore a patent holder to the position that they would have occupied had there been no infringement. ${ }^{94}$

Of course, this is only the first step in Yale Lock's analysis. Aro does not mention the second apportionment step. This omission is not surprising given the context. Aro was explaining that the patent holder could not obtain a double recovery from different joint tortfeasors. ${ }^{95}$ There was no reason to go into the details of how to calculate lost profits. Indeed, the term "lost profits" does not even appear in the decision. Moreover, Aro certainly did not grapple with the additional complexity that arises when considering apportionment. Courts and commentators alike have nonetheless relied on both Aro and Yale Lock to suggest that calculating lost profits boils down to applying a "but for" causation analysis and nothing more. ${ }^{96}$ As a result, the concept of apportionment has disappeared from modern lost profits doctrine.

\section{The Growth of "But For" Analysis}

Even though Aro's discussion of "but for" causation was dicta, courts have clearly accepted Aro's abridged version of Yale Lock as both accurate and complete. Consider Panduit Corp. v. Stahlin Bros. Fibre Works, the Sixth Circuit's 1978 decision that is widely cited for its four-factor test used to determine lost profits. ${ }^{97}$ Panduit relied on both Aro and Yale Lock for the proposition that damages for patent infringement under 35 U.S.C. $\S 284$ should be calculated using "but for" analysis. ${ }^{98}$ As stated earlier, each of Panduit's four factors expresses a different aspect of "but for" analysis. ${ }^{99}$ Despite quoting Yale Lock, Panduit does not suggest that apportionment is part of the lost profits calculation. In other words, Panduit relies on Yale Lock's step one "but for" analysis yet omits its step two apportionment analysis.

${ }^{94} I d$. at 507 ("[Patent damages] have been said to constitute 'the difference between [the patentee's] pecuniary condition after the infringement, and what his condition would have been if the infringement had not occurred."' (quoting Yale Lock, 117 U.S. at 552)).

${ }^{95} I d$. at 512 (noting that the discussion "is but an application of the rule that full satisfaction received from one tortfeasor prevents further recovery against another").

${ }^{96}$ See infra notes $97-114$.

${ }^{97}$ Panduit Corp. v. Stahlin Bros. Fibre Works, 575 F.2d 1152, 1156 (6th Cir. 1978).

${ }^{98}$ See id. ("'Patent damages] have been said to constitute 'the difference between [the patentee's] pecuniary condition after the infringement, and what his condition would have been if the infringement had not occurred." (quoting Yale Lock, 117 U.S. at 552) (citing Aro, 377 U.S. at 507)).

\footnotetext{
${ }^{99}$ See supra notes $29-31$ and accompanying text.
} 
To be fair, the question of apportionment was not at issue in Panduit. The patent holder was unable to recover any lost profits because the Sixth Circuit held that it had failed to satisfy Panduit's fourth factor. ${ }^{100}$ There was insufficient evidence to show the amount of profits the patent holder would have made but for the defendant's infringement. ${ }^{101}$ Because the patent holder had failed to show that it deserved any lost profits, the court did not need to discuss whether to apportion those profits or how to do so. The problem, however, is that most courts accept the Panduit factors as complete regarding lost sales. Courts regularly instruct juries about the four Panduit factors without mentioning apportionment. ${ }^{102}$

Panduit's interpretation of Aro and Yale Lock hardly stands alone. In 1995, in Rite-Hite Corp. v. Kelley Co., an en banc panel of the Federal Circuit applied a "but for" analysis to extend the reach of lost profits recoveries. ${ }^{103}$ Quoting Aro, which was itself quoting Yale Lock, the Federal Circuit held that the patent holder's lost profits could encompass additional sales that it would have made for products that did not use the patented invention. ${ }^{104}$ Interestingly, four of the judges took a contrary view and interpreted Aro in much the way this Article does. Judge Nies' dissent argued that Aro was "simply addressing preclude[ing] double recovery" and that it did not hold that "but for" analysis was the only limitation on damages. ${ }^{105}$ The majority opinion avoided addressing this particular point, and subsequent decisions continue to rely on Aro and Yale Lock to focus exclusively on "but for" analysis.

${ }^{100}$ Panduit, 575 F.2d at 1156.

${ }^{101} I d$. at $1156-57$.

102 See, e.g., Federal Circuit Bar Association, Model Patent Jury Instructions $\S \S 6.2-.4$ (2016); Northern District of California, Model Patent Jury Instructions, $\S \S 5.3-.5(2015)$.

${ }^{103}$ Rite-Hite Corp. v. Kelley Co., 56 F.3d 1538, 1546 (Fed. Cir. 1995).

${ }^{104} \mathrm{Id}$. at 1545 ("The question to be asked in determining damages is 'how much had the Patent Holder and Licensee suffered by the infringement. And that question [is] primarily: had the Infringer not infringed, what would the Patentee Holder-Licensee have made?'” (quoting Aro, 377 U.S. at 507)). The court then went on to say:

Recovery for lost sales of a device not covered by the patent in suit is not of course expressly provided for by the patent statute. Express language is not required, however .... [D]amages should be awarded "where necessary to afford the plaintiff full compensation for the infringement." Thus, to refuse to award reasonably foreseeable damages necessary to make Rite-Hite whole would be inconsistent with the meaning of $\S 284$.

Id. at 1546-47 (quoting Gen. Motors Corp. v. Devex Corp., 461 U.S. 648, 654 (1983)).

${ }^{105} \mathrm{Id}$. at 1558 (Nies, J., dissenting in part). Judge Nies' opinion also relied on historical Supreme Court precedent apportioning lost profits to rebut the view that damages should be calculated using "but for" analysis. Id. at 1565-66. 
The "but for" analysis in patent law is not boundless. The Rite-Hite majority noted that courts have used the concepts of "proximate cause" or "foreseeability" to limit damages. ${ }^{106}$ Applying those principles to patent law, the court said that, "[i]f a particular injury was or should have been reasonably foreseeable by an infringing competitor ... that injury is generally compensable absent a persuasive reason to the contrary." 107 Although the foreseeability limitation is concerned with remote injuries, that limitation does apply to the lost profits cases at issue here. Losing sales to an infringing competitor is not a remote injury; it is entirely foreseeable. Thus, the issue is not whether to compensate the patentee for these injuries. The issue is simply determining the proper amount of compensation. Limitations based on proximate cause do not help determine that amount. ${ }^{108}$

Notably, the current critique of Rite-Hite's "but for" analysis has implications for other areas of damages law beyond apportionment. ${ }^{109}$ It suggests that several different damages theories are built upon shaky precedent, including Rite-Hite's holding that patentees can recover lost profits for sales of unpatented products. ${ }^{110}$ It may also cause us to reconsider whether a patentee should be able to recover lost profits for so called "convoyed sales" or unpatented items sold with the patented item. ${ }^{111}$ Moreover, my critique made elsewhere buttresses claims that "but for" analysis should take a back

${ }^{106}$ Id. at 1546 (majority opinion).

${ }^{107}$ Id. Although Rite-Hite specifically addressed foreseeability, it also noted that other tools like "logic, common sense, justice, policy and precedent" have been used to limit legal responsibility. Id. (quoting W. PAGe KeEton et AL., Prosser AND KeEtON ON the LAW OF TORTS § 42, at 279 (5th ed. 1984)).

${ }^{108}$ Indeed, tort law has confronted similar issues. Prosser suggests that once causation is established, and when feasible, apportionment should be used to limit a defendant's liability to that part of the harm of which defendant's conduct has been a cause in fact. WILLIAM L. PROSSER, HANDBOOK OF THE LAW OF TORTS § 52, at 313-14 (4th ed. 1971).

${ }^{109}$ See Sichelman, supra note 6, at 538 (providing a policy-based critique of "make whole" patent remedies and asserting that "make-whole remedies may impede efficient levels of innovation").

${ }^{110}$ See Rite-Hite, 56 F.3d at 1547. Others have criticized this holding on policy grounds. See, e.g., Christina Bohannan \& Herbert Hovenkamp, Creation Without Restraint: ProMOTING LIBERTY AND RIVALRY IN INNOVATION 52 (2012) (noting that "when innovations are cumulative, interconnected, or exist in complementary relationships, a rule giving the entire surplus to the inventor is not even conceptually possible"); see also Timothy Holbrook, Boundaries, Extraterritoriality, and Patent Infringement Damages, 92 NOTRE DAME L. REV. 1745, 1793 (2017) (noting that "[i]t may be time to revisit the foreseeability/proximate cause aspect of RiteHite").

${ }^{111}$ See e.g., Rite-Hite, 56 F.3d at 1550 (stating that lost profits could apply to unpatented items that form a "functional unit" with the patented item); Paper Converting Mach. Co. v. Magna-Graphics Corp., 745 F.2d 11, 23 (Fed. Cir. 1984) (allowing lost profits damages for different pieces of equipment in a rewinder assembly even though the patent only covered a single machine in that assembly). 
seat to comity concerns when thinking about extraterritorial damages. ${ }^{112}$ These topics, however, are beyond the scope of this Article and will be left for another day.

Bringing the discussion back to Mentor Graphics, we can see that the opinion carried forward Rite-Hite's misunderstanding of precedent. Mentor Graphics justified calculating lost profits relying solely on "but for" analysis by citing Aro and Yale Lock and saying that "Section 284 damages 'have been said to constitute the difference between [the patentee's] pecuniary condition after the infringement, and what his condition would have been if the infringement had not occurred.",113

Just as in Rite-Hite, the Federal Circuit in Mentor Graphics made two mistakes. It failed to appreciate that Yale Lock applied a two-step approach to calculating lost profits that included apportionment. Also, the court did not understand that the comments regarding "but for" causation in Aro were an afterthought unrelated to the issue that the Supreme Court was addressing in that case. This mistake is easy to make today, and many modern commentators have perpetuated this misunderstanding. ${ }^{114}$ It is not too late, however, to correct the error. Either the Federal Circuit or the Supreme Court can take a closer look at these Supreme Court decisions now, and restore apportionment principles to lost profits calculations.

\section{D. “But For" $\neq$ Apportionment}

Unlike other modern decisions refusing to use apportionment in lost profits calculations, the original panel decision in Mentor Graphics conceded that apportionment applied to all types of damages calculations, including lost profits. ${ }^{115}$ The opinion took the odd position, however, that "but for" analysis somehow incorporates apportionment principles. ${ }^{116}$ Specifical-

${ }^{112}$ Bernard Chao, Patent Imperialism, 109 Nw. U. L. REV. ONLINE 77, 83-86 (2014), https:// scholarlycommons.law.northwestern.edu/cgi/viewcontent.cgi?referer=https://www.google.com/ \&httpsredir=1\&article=1008\&context=nulr_online [https://perma.cc/WSR5-XMZ7]; see also Carnegie Mellon Univ. v. Marvell Tech. Grp., Ltd., 807 F.3d 1283, 1306 (Fed. Cir. 2015) (rejecting "but for" analysis that would allow patentees to capture damages for sales made abroad).

${ }^{113}$ Mentor Graphics, 851 F.3d at 1283-84 (quoting Yale Lock, 117 U.S. at 552) (citing Aro, 377 U.S. at 507). The decision went on to rely on Rite-Hite and Panduit. Id. at 1284-85.

${ }^{114}$ See, e.g., Bernard Chao, The Infringement Continuum, 35 CARDOZO L. REV. 1359, 1397 n.208 (2014); Ned Conley, An Economic Approach to Patent Damages, 15 AIPLA Q.J. 354, 368 (1987) (citing articles to either or both Aro and Yale Lock for applying straightforward "but for" analysis); Jerry A. Hausman, Gregory K. Leonard \& J. Gregory Sidak, Patent Damages and Real Options: How Judicial Characterization of Non-Infringing Alternatives Reduced Incentives to Innovate, 22 BERKELEY TECH. L.J. 825, 833 n.23 (2007).

${ }^{115}$ Mentor Graphics, 851 F.3d at 1287.

${ }^{116}$ See id. at 1288 (asserting that apportionment "was properly incorporated into the lost profits analysis ... through the Panduit factors"). 
ly, the court said that, "Panduit's requirement that patentees prove demand for the product as a whole and the absence of non-infringing alternatives ties lost profit damages to specific claim limitations and ensures that damages are commensurate with the value of the patented features." ${ }^{, 17}$ As explained earlier, however, the Panduit factors simply reflect different specific aspects of "but for" causation. ${ }^{118}$ They do not reduce lost profit awards based on other factors that may contribute to a product's success.

Perhaps recognizing that the original panel's analysis was flawed, an en banc session of the Federal Circuit denied rehearing on a wholly different basis. ${ }^{119}$ Rather than suggesting that the Panduit factors somehow incorporated apportionment, the en banc opinion said that meeting the Panduit factors satisfied the entire market value rule, making apportionment unnecessary. ${ }^{120}$ The entire market rule is neither apportionment nor a substitute for it. Rather, the entire market rule says that if the patentee can show that "the patented feature drives the demand for an entire multi-component product, a patentee may be awarded damages as a percentage of revenues or profits attributable to the entire product." ${ }^{121}$ Notably, the entire market rule only says when the "entire product" can be used, but not the appropriate "percentage." 122 That latter issue is a distinct question that apportionment answers.

Yet the en banc opinion reasoned that the first two Panduit factors, "“demand for the patented product' (factor one) and an 'absence of acceptable noninfringing substitutes' (factor two)" 123 together contemplate "demand for the patented product as a whole" as well as the particular features of the claimed invention in particular. ${ }^{124}$ Relying on these statements, the opinion concludes that "further apportionment is unnecessary." 125 The text of these factors belies the Federal Circuit's reasoning. The two factors only discuss the infringing product but they fail to mention the specific infring-

${ }^{117}$ Id

${ }^{118}$ See supra notes 7-8 and accompanying text.

${ }^{119}$ Mentor Graphics II, 870 F.3d at 1300.

${ }^{120} \mathrm{Id}$. The entire market value rule allows a patentee to obtain compensation based on the market price for a multicomponent product when their infringed-upon patent is only for one of the components. Yang, supra note 23, at 654. This rule puts the patentee in the position it would have been in without the infringement because without the infringement, the patentee could have made and sold its own multicomponent product. Id; see also Mentor Graphics II, 870 F.3d at 1300.

${ }^{121}$ See, e.g., LaserDynamics, Inc. v. Quanta Comput., Inc., 694 F.3d 51, 67 (Fed. Cir. 2012) (emphasis added).

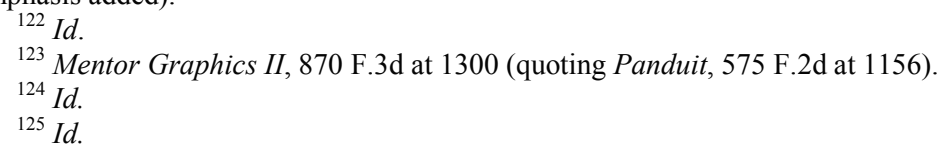


ing features. Thus, there is no way for the Panduit test to consider the particular patented features.

Instead, the first two Panduit factors serve the same function as the entire market value rule. They serve to identify the universe of profits at issue -in other words, the correct base to consider. Like the entire market value rule, however, they do not say what portion of those profits should be apportioned to the infringing feature. That is supposed to occur when the fact finder applies Yale Lock's second step - apportionment. Unfortunately, that step has disappeared from the Federal Circuit's lost profits jurisprudence.

\section{CALIBRATING DAMAGES}

This Article does not endorse the use of apportionment based on precedent alone. There are several policy reasons that weigh in favor of using apportionment to calculate lost profits. Part III explains the reasons in favor of apportionment and criticizes the current method for calculating lost profits. ${ }^{126}$ First, Part III explains how the Supreme Court has recently refused to allow patent holders to recover remedies on entire products in the context of both permanent injunctions and design patents. ${ }^{127}$ It then argues that by failing to focus on the infringing feature, lost profits law is inconsistent with how these other remedies value patent rights. ${ }^{128}$ Second, Part III explains why awarding lost profits on entire infringing products overcompensates patentees and disincentivizes complementary innovation. ${ }^{129}$ This can be particularly problematic because the current test allows for multiple "but for" causes. As a result, an infringer may ultimately be liable for multiple awards that sweep up all of a products' profits. Third, Part III addresses the critics of apportionment by arguing that concerns about making patentees whole, although understandable, should not be prioritized over properly allocating innovation incentives. ${ }^{130}$ As part of this argument, Part III explains why the failure to apportion profits results in a very similar problem to that found in discussion of patent holdup. ${ }^{131}$ Fourth, Part III explains how basing lost profits on entire products leads to uneven treatment of similarly situated companies. ${ }^{132}$ Finally, Part III rejects Mentor Graphics Corp. v.

\footnotetext{
${ }^{126}$ See infra notes 134-195 and accompanying text.

${ }^{127}$ See infra notes 136-152 and accompanying text.

${ }^{128}$ See infra notes 153-160 and accompanying text.

129 See infra notes 161-182 and accompanying text.

${ }^{130}$ See infra notes 183-193 and accompanying text.

${ }^{131}$ See infra notes 187-188 and accompanying text.

${ }^{132}$ See infra note 194 and accompanying text.
} 
EVE-USA, Inc.'s conclusion that "but for" analysis somehow incorporates apportionment principles. ${ }^{133}$

\section{A. Infringing Feature $<<$ Infringing Product}

The primary policy reason for using apportionment is to properly calibrate lost profits awards to the value of the patented invention. It may seem self-evident that a patent on part of a product is entitled to a smaller reward than a patent on the entire product. Patentees have nonetheless repeatedly sought to obtain remedies based on the entire product when the patent covered just an aspect of the product.

Allowing patentees a disproportionately large remedy harms innovation by disincentivizing others from developing complementary technology that either builds on or works with other technology. ${ }^{134}$ To illustrate, imagine giving the inventor of a fundamental television technology the right to capture all of the profits from any kind of television, even those that incorporate later-developed improvements. In other words, assume that any kind of television would infringe that patent. Other inventors would have no incentive to develop better televisions because the original patentee would get all of the profits. As a result, neither high definition television nor playback features would be invented until the original patent expired. These concerns should not be overemphasized because lost profits law does not affect innovators nearly as much as the more common remedy of reasonable royalties. ${ }^{135}$ The relatively infrequent use of lost profits law, however, should not prevent us from adopting rules that identify precisely what the patentee deserves.

Recognizing this problem, the Supreme Court recently overturned two attempts to obtain remedies based on the entire product in the context of injunctions and design patent damages. The first such decision was $e B a y$ Inc. v. MercExchange, L.L.C. in $2006 .{ }^{136}$ For many years, courts automatically awarded prevailing patentees a permanent injunction against further

${ }^{133}$ See infra note 195 and accompanying text.

${ }^{134}$ See Scotchmer, supra note 9, at 32-33 (explaining that later innovators also need incentives to build on patented technology); see also Amy L. Landers, Patent Claim Apportionment, Patentee Injury, and Sequential Invention, 19 GEO. MASON L. REV. 471, 504-09 (2012) (relying on the economics of cumulative invention to make the case for apportionment in calculating reasonable royalties).

${ }^{135}$ PWC, 2015 Patent Litigation Study: A Change in Patentee Fortunes 8 (2015), https://www.pwc.com/us/en/forensic-services/publications/assets/2015-pwc-patent-litigation-study. pdf [https://perma.cc/NGR6-G4TL] (finding that $81 \%$ of damages awards between 2005 and 2014 contained a reasonable royalties component while only $31 \%$ contained a lost profits component).

${ }_{136}$ eBay Inc. v. MercExchange, L.L.C., 547 U.S. 388, 392-94 (2006). 
infringement. ${ }^{137}$ That, however, gave patentees owning patents covering part of a product the ability to enjoin a company from making and selling the product as a whole. In some cases, infringers could redesign their products to exclude the infringing feature, but those costs might actually be higher than the value of the patented technology. ${ }^{138}$ In other cases, the patent may cover technology essential to making the larger product. Examples include patents on interfaces or patents essential to making products comply with different technical standards, or "standards essential patents." 139 These kinds of patents gave their owners the ability to "hold up" manufacturers and demand settlements that were far larger than the value the patented invention actually contributed to the product. ${ }^{140}$

Although the primary rationale underlying eBay was restoring traditional equitable principles to patent law injunctions, several Justices were also concerned about holdup. ${ }^{141}$ eBay requires courts to apply the same traditional four-factor test they use in other areas of the law when determining if an injunction should be issued. ${ }^{142}$ Lower courts have interpreted eBay's

four-factor test as ensuring a focus on the infringing feature. ${ }^{143}$ Specifically, when assessing the first factor-whether continued infringement will cause the patentee irreparable harm - the Federal Circuit has held that there must

${ }^{137} I d$. at 391 (discussing the prior rule granting permanent injunctions on infringement "absent exceptional circumstances").

${ }^{138}$ See Mark A. Lemley \& Carl Shapiro, Patent Holdup and Royalty Stacking, 85 TEX. L. REV. 1991, 2002 (2007) (explaining when settlement values might be closer to redesign costs as opposed to the value of the contribution the patent makes to the overall product).

139 See Bernard Chao, Horizontal Innovation and Interface Patents, 2016 WIS. L. REV. 287, 316 (describing, for example, why other companies want access to patents covering things like Apple's interfaces that reach millions of Apple customers).

${ }^{140}$ See Lemley \& Shapiro, supra note 138, at 2008-10 (describing how injunctions against an entire product can result in patent holdup).

${ }^{141}$ eBay, 547 U.S. at 396-97 (Kennedy, J., concurring) (joined by Stevens, Souter, and Breyer, JJ.) (suggesting that courts can avoid holdup by awarding damages instead of an injunction "[w]hen the patented invention is but a small component" of a larger product).

${ }^{142} I d$. at 391 (majority opinion). Those factors are: (1) whether the plaintiff has suffered an irreparable harm, (2) whether there is an adequate remedy at law, (3) the balance of hardships on the respective parties, and (4) whether granting an injunction would disservice the public interest. See id.

${ }^{143}$ See, e.g., Apple, Inc. v. Samsung Elecs. Co., 678 F.3d 1314, 1324 (Fed. Cir. 2012). 
be a "causal nexus" between the infringing feature and demand for the infringing product. ${ }^{144}$ This rule limits the problem of patent holdup. ${ }^{145}$

In a suit between smartphone titans in the Northern District of California which began in 2011, Samsung Electronics Co. v. Apple Inc., a jury found that Samsung infringed various Apple design patents. ${ }^{146}$ The jury awarded Apple \$399 million in damages, representing "the entire profit Samsung made from its sales of the infringing smartphones." 147 Consider one of the design patents involved (depicted above). ${ }^{148}$ The patent claim only covers the black, flat front face of the phone. The idea that the owner of a design patent covering a phone case can recover all of the profits of a product as complex as a smartphone makes no economic sense. As one scholar put it, "As applied to a modern, multicomponent product it drastically overcompensates the owners of design patents, and correspondingly undervalues technical innovation and manufacturing know-how." ${ }^{149}$ Indeed, the huge Samsung jury verdict suggests that the tens of thousands of other patents that smartphones use have no value. ${ }^{150}$

The Supreme Court wisely rejected the lower court's ruling in Samsung Electronics in 2016, holding that the term "article of manufacture" in 35 U.S.C. $§ 289$ could apply to "both a product sold to a consumer and a component of that product, whether sold separately or not." ${ }^{151}$ The Court relied on a statutory construction unique to design patents, not on policy, and thus its decision does not have a broad impact on other areas of the law. Samsung Electronics, however, does advance an important policy goal. By

${ }^{144}$ Apple Inc. v. Samsung Elecs. Co., 735 F.3d 1352, 1364 (Fed. Cir. 2013). Unfortunately, the Federal Circuit subsequently watered down the causal nexus requirement in yet another smartphone decision. Apple Inc. v. Samsung Elecs. Co., 809 F.3d 633, 641 (Fed. Cir. 2015). This new standard is misguided. See Chao, Causation and Harm, supra note 4, at 74-76.

${ }^{145}$ Chao, Causation and Harm, supra note 4, at 75-76.

${ }^{146}$ Samsung Elecs. Co. v. Apple Inc., 137 S. Ct. 429, 433 (2016).

${ }^{147}$ Id. Although lost profits for infringement of the more common utility patents are focused on what the patent owners lost, the remedy for infringing a design patent allows recovery of the infringer's profits. See 35 U.S.C. $§ 289$ (2012) (stating the design patent infringer "shall be liable to the [patent] owner to the extent of his total profit, but not less than $\$ 250$ ").

${ }^{148}$ U.S. Patent No. D618,677 S (issued June 29, 2010).

${ }^{149}$ Mark A. Lemley, A Rational System of Design Patent Remedies, 17 Stan. TeCh. L. Rev. 219, 221 (2013); see also Peter Lee \& Madhavi Sunder, The Law of Look and Feel, 90 S. CAL. L. REV. 529, 590 (2017) (positing that awarding all profits for design patent infringements "may vastly overcompensate [the patentee] and may not reflect the true economic contribution of the design to the product").

${ }^{150}$ See Steve Lohr, Apple-Samsung Case Shows Smartphone as Legal Magnet, N.Y. TIMES (Aug. 25, 2012), https://www.nytimes.com/2012/08/26/technology/apple-samsung-case-showssmartphone-as-lawsuit-magnet.html (noting that "as many as 250,000 patents can be used to claim ownership of some technical or design element in a smartphone").

${ }^{151}$ Samsung, 137 S. Ct. at 436. 
explaining that a design patent may only cover a part of a product, the new rule effectively requires courts to at least consider applying a form of apportionment to the recovery of design patent damages.

By solely using "but for" analysis, Mentor Graphics accomplished precisely what both eBay and Samsung Electronics rejected. Mentor Graphics provided a remedy based on the entire infringing product and not only the patented feature. In contrast, one of the ways that $e B a y$ reduced patent holdup was to make it much harder for patent holders to prevent someone from obtaining an injunction against an entire product when the patent only covered a component of it. ${ }^{153}$ Likewise, Samsung Electronics reduced the likelihood that a design patent owner could recover all of the profits earned from an infringing product when the patent only covers one aspect of that product. Courts must now consider whether the article of manufacture covered by a design patent is simply a component. If it is, the patent holder will only recover profits attributable to that component, and not those attributable to the entire product.

In contrast, relying exclusively on "but for" analysis fails to distinguish between lost profits attributable to a feature and lost profits attributable to the entire product; under "but for" analysis, they are one and the same. ${ }^{154}$ The facts of Mentor Graphics clearly illustrate this point. Mentor Graphics obtained $\$ 36,417,661$, which represents all of the profits that Mentor Graphics would have made but for the sale of Synposys' infringing products. ${ }^{155}$ Presumably, the result would have been the same if the infringing product incorporated technology covered by ten, or even one hundred, other patents. ${ }^{156}$ Indeed, Mentor Graphics did not even lower its damages

${ }^{152}$ See Sarah Burstein, The "Article of Manufacture” in 1887, 32 BERKELEY TECH. L.J. 1, 76 (2017) (relying on a historical perspective to suggest that the "article of manufacture" in Samsung Electronics was not the entire smartphone but the "bezel and the screen conglomeration").

${ }^{153}$ See Mark A. Lemley \& Philip J. Weiser, Should Property or Liability Rules Govern Information?, 85 TEX. L. REV. 783, 795 (2007) (noting that "when injunctive relief is not well tailored to the rights being protected, courts are left with the choice of giving no protection or giving too much protection").

${ }^{154}$ This was one of the primary reasons historical precedent used apportionment. See, e.g., Philp v. Nock, 84 U.S. (17 Wall.) 460, 462 (1873) ("Where the infringement is confined to a part of the thing sold, the recovery must be limited accordingly."); Seymour v. McCormick, 57 U.S. (16 How.) 480, 489 (1853) (stating that "one who invents some improvement in the machinery of a mill could not claim that the profits of the whole mill should be the measure of damages for the use of his improvement").

${ }^{155}$ Mentor Graphics Corp. v. EVE-USA, Inc., 851 F.3d 1275, 1287 (Fed. Cir. 2017).

${ }^{156}$ These numbers are quite realistic, as Mentor Graphics apparently had over a hundred active patents on emulation technology. Opening Brief and Addendum of Defendants-Appellants EVE-USA, Inc. at 48, Mentor Graphics, 851 F.3d 1275 (Nos. 15-1470, 15-1554, 15-1556). The documents that supposedly illustrate this point were filed under seal and unavailable. 
demand after it lost four of the five patents it had been asserting. ${ }^{157}$ In the "but for" damages world, prevailing on any one sufficiently important patent means that a patentee recovers all of the lost profits associated with the infringing product.

Moreover, Synopsys was not allowed to introduce evidence that there were "multiple drivers of [customer] demand." 158 That information is irrelevant if the specific value of the infringing feature is not used to determine damages. This is not supposition; it is what the district court judge said:

I am just saying you cannot apportion. When you start saying, "Here is how much of the purchase price for each sale was really driven by other features," then other than on royalty, it doesn't come up. That's apportionment. ${ }^{159}$

Of course, the end result is that the patentee recovers lost profits on the entire product. This result clearly conflicts with the policy underlying both eBay and Samsung. ${ }^{160}$ If left standing, the rule will overcompensate patent holders and unnecessarily burden companies that make and sell multicomponent products.

\section{B. Royalty Stacking}

A related critique of relying solely on "but for" lost profits analysis is the concern about overlapping patent rights. Here, the concern is not just about the outsized remedy that a patent on a single feature receives, but how that remedy interacts with all of the other patents involved in multicomponent products. Modern technology products often use hundreds, if not hundreds of thousands, of patented inventions. ${ }^{161}$ Those patents are often owned by many different parties. The "royalty stacking" problem occurs when these different patent owners demand higher aggregate royalties than

${ }^{157} \mathrm{Id}$. at 49 . The documents underlying these statements were also under seal.

${ }^{158}$ Transcript of Record of October 8, 2014, supra note 46 at 1649.

${ }^{159} \mathrm{Id}$. at 1650 .

${ }^{160}$ This concern is not new and is one of the primary reasons that the Supreme Court adopted apportionment years ago. See Seymour, 57 U.S. at 490-91 (reversing a jury instruction that allowed a patent holder to recover damages on the entire machine when the patent only covered an improvement).

${ }^{161}$ See Jorge L. Contreras, Technical Standards, Standards-Setting Organizations and Intellectual Property: A Survey of the Literature (with an Emphasis on Empirical Approaches), in 2 ANALYTICAL METHODS: RESEARCH HANDBOOKS ON THE ECONOMICS OF INTELLECTUAL PROPERTY LAW (forthcoming) (manuscript at 8-9), https://dc.law.utah.edu/cgi/viewcontent.cgi?referer=https:// www.google.com/\&httpsredir=1\&article=1010\&context=scholarship [https:/perma.cc/MCL4-FT2T] (listing studies that identified thousands to hundreds of thousands of patents that potentially cover various technical standards); see also Chao, The Infringement Continuum, supra note 114, at 1399; supra note 97 and accompanying text. 
they would have had they acted as a group. ${ }^{162}$ If the combination of patent licenses and damages awards become excessive, this will likely deter later innovation. ${ }^{163}$ That risk is only heightened when a single award amounts to all of the profits that a patent holder would have made. In Mentor Graphics, Synopsys raised one variation of this concern when it pointed out that products may contain many features patented by different companies, and each of those patented features could be a "but for" cause of a company's sales. ${ }^{164}$

The Federal Circuit in Mentor Graphics concluded that this situation was unrealistic because "[u]nder Panduit ... there can only be one recovery of lost profits for any particular sale." 165 The opinion illustrated its point using a laptop example offered by Synopsys. In the example, customers demand a number of separate features in a laptop, including a high resolution screen, a responsive keyboard, a fast wireless network receiver, and an extended-life battery. ${ }^{166}$ The opinion reasoned that "[i]f each are patented by separate companies, and no manufacturer has the right to sell them all, then no manufacturer could obtain lost profits on such a laptop (none could satisfy the demand for everything)." 167 The patentee can only recover a reasonable royalty. ${ }^{168}$ On the other hand, if the only patented component is the extended life battery, "one patentee can obtain lost profits on the overall product." ${ }^{169}$ Thus, the court in Mentor Graphics reasoned that there can only be one patent that ever gives rise to lost profits recovery.

The Federal Circuit's analysis, however, is flawed on several levels. First, it fails to even discuss the more fundamental concern of royalty stacking. Second, with respect to the narrower question of multiple "but for" causes, the opinion fails to appreciate how the Panduit test creates a hypothetical world with no non-infringing alternatives. This hypothetical world looks different when different patents are at issue in a particular lawsuit. The result is that there may be different "but for" causes depending on what patent is being asserted. Alternatively, the opinion may actually be adding a new element to the Panduit test for lost profits that does not exist and makes little sense be-

${ }^{162}$ Contreras, supra note 161 , at 18-19.

${ }^{163}$ See Lemley \& Shapiro, supra note 138, at 2015-16 ("[T] he combined royalty burden associated with royalty stacking may make it unprofitable for the downstream firm to conduct the $\mathrm{R} \& \mathrm{D}$ and incur the other costs necessary to develop the product in question.").

${ }^{164}$ Mentor Graphics, 851 F.3d at 1289.

${ }^{165} \mathrm{Id}$.

${ }^{166} \mathrm{Id}$.

${ }^{167} \mathrm{Id}$.

${ }^{168} \mathrm{Id}$.

${ }^{169}$ Id. at 1289-90. 
cause it assumes knowledge that real-world companies do not possess. The following two subsections explain these arguments in further depth.

\section{Excessive Payments}

This subsection first addresses the larger concern: whether a single award based on all of a patent holder's lost profits will force an infringer to pay excessive fees for all of the patent rights that it must acquire. Keep in mind that this problem exists even if we accept Mentor Graphics' proposition that there is only one patented feature that drives consumers' purchasing decisions. ${ }^{170}$ Consider the situation in which the Federal Circuit decision is left standing and Synopsys pays Mentor Graphics the \$36 million award in lost profits. If we use Mentor Graphics' profits per emulator as a rough estimate of the profits that Synopsys made, the result is that Synopsys just paid all of its profits for a license to a single patent.

This outcome makes little economic sense because a product's entire value is not attributable to one patent. What happens when a third-party patent holder later approaches Synopsys, demanding that it license the thirdparty patent because of past infringement? If Synopsys has already paid all of its profits to Mentor Graphics, then the payment of any additional royalties will mean that Synopsys sold its emulators at a loss. ${ }^{171}$ Even if the other patented feature is relatively minor, that third-party patentee is still entitled to a royalty. In other words, it is quite possible that a manufacturer must obtain a license to a critical patent (i.e. if infringed would result in a lost profits award) in addition to less important patents (i.e. where lost profits are unavailable but a payment of a reasonable royalty is still required). If the infringer must pay all of the patentee's lost profits for the use of the critical patent, that will eliminate crowd out the infringer's ability to pay for other licenses and earn any profits. It will also prevent the infringer from earning a return on the investments it made in technologies that likely also contributed to the infringing product's success. ${ }^{172}$

${ }^{170} I d$.

171 The profits that defendant Synopsys earned are not necessarily the same as Mentor Graphics' lost profits. In multicomponent contexts, however, there is no reason to believe that one party's (the infringer or the patentee's) profits will be systematically higher than the other's. That is especially true when there is no evidence that the infringer avoided investing in research and development by copying. Thus, for simplicity's sake, we can assume that their per product profit was roughly the same.

172 See Brian J. Love, Patentee Overcompensation and the Entire Market Value Rule, 60 STAN. L. REV. 263, 264-65, 280 (2007) (noting that the entire market value rule causes a similar problem for reasonable royalty calculations and asserting that "if a producer of a complex product has already been compelled to pay a reasonable royalty to a patentee based on the entire value of 
This analysis does not even consider all of the non-patent reasons why a product is profitable, which may include the company's reputation. ${ }^{173}$ For example, Apple can charge a premium that other lesser known companies cannot. Larger profits are also obtained by taking greater risks. Companies can have trade secrets, better employees, and general know-how that all contribute to the bottom line. A damages award that captures all of the infringer's profits assumes that none of these factors contribute to a product's success. ${ }^{174}$

\section{Multiple "But For" Causes}

The Federal Circuit has concluded that there can only be one patent that is the "but for" cause of lost profits. This issue, however, is less important than the royalty stacking problem. That is because the multiple "but for" problem undoubtedly occurs far less frequently than situations where a multicomponent product is covered by many less critical patents. For these cases, the problem is that a company will have to make both a hefty lost profits payment and many presumably smaller reasonable royalty payments. If there are multiple "but for" causes, the problem is magnified because the company will make multiple substantial lost profits payments. The Mentor Graphics decision relied heavily on the belief that there can be only one "but for" cause to reject apportionment. As discussed below, that analysis is wrong. ${ }^{175}$

Mentor Graphics said that there can only be one "but for" cause because "there can only be one recovery of lost profits for any particular sale." ${ }^{176}$ On its face, this conclusion seems quite plausible. Recall the laptop example. If a laptop manufacturer is infringing two separate patents covering a high-resolution screen and a fast-wireless network receiver, both patent holders will not be able to prove lost profits at the same time. Remember that, to recover lost profits, each patentee must show that if there had been no infringement, customers would have purchased the patentee's products instead of the infringer's products. If the owner of the highresolution screen patent, however, shows that the infringing manufacturer's customer would have purchased its laptop, that means that the customer

\footnotetext{
the complex product, the producer has effectively compensated the patentee for the value contributed by each and every component of that product").

${ }^{173}$ See Lemley, supra note 24, at 663 ("Most commonly, other patents also contribute to [a] product ... [and] know-how, materials, and marketing efforts almost always contribute some value.") (citation omitted).

${ }^{174}$ This is also inconsistent with the Yale Lock analysis discussed above. See supra notes 8082 and accompanying text.

${ }^{175}$ See infra notes 176-182 and accompanying text.

${ }^{176}$ Mentor Graphics, 851 F.3d at 1289.
} 
would not have purchased the laptop from the owner of fast-wireless. The reverse is also true. If the evidence shows that the customer would have purchased a laptop from the owner of the fast-wireless patent, the evidence clearly cannot show that the customer would have purchased a laptop from the high-resolution screen patent holder.

This analysis, however, assumes that the Panduit factors are attempting to determine what would have happened in the real world had there been no infringement. That is only partially true. The second Panduit factor modifies what is otherwise a real-world determination by pretending that "but for" the infringement, the infringer's customers would not have chosen to purchase products from an infringing third party. ${ }^{177}$ The rationale for this modification makes sense. It allows the patentee to recover lost profits even when the infringer's customers would have chosen a third party's infringing products in the absence of the defendant's infringement. An unforeseen consequence of this rule, however, is that juries in separate lawsuits may find different "but for" causes. In other words, one jury may find that an infringer's customers would have purchased products from patentee A "but for" the infringement of patent A, while a second jury may find that the same customer would have purchased products from patentee $B$, but for the infringement of patent B.

Consider Mentor Graphics' laptop example in the context of two separate lawsuits. Assume that the owner of the high-resolution screen patent sues the laptop manufacturer and shows that customers insist on purchasing laptops with high-resolution screens. This evidence will allow the patentee to prove that "but for" the infringement of the high-resolution screen patent, the infringer's customers would have purchased the patentee's laptop. The second Panduit factor prevents the jury from considering the possibility that customers would have purchased laptops from the other manufacturers (including the fast-wireless patent holder) because they do not sell noninfringing alternatives, or they do not have a license to the high-resolution screen patent.

Now assume that the owner of the fast-wireless patent sues the same laptop manufacturer in a second and separate lawsuit. The owner of the fastwireless patent will also be able to present evidence that customers insist on purchasing laptops that have a fast-wireless connection. This evidence can be used to prove that "but for" the infringer's sales, customers would have purchased laptops from the owner of the fast-wireless patent. Again, the

${ }^{177}$ Panduit Corp. v. Stahlin Bros. Fibre Works, 575 F.2d 1152, 1156 (6th Cir. 1978). The second factor asks whether non-infringing alternative products were available to the infringer's customers. Id. 
second Panduit factor prevents the jury from considering evidence that customers would have purchased laptops from the owner of the high-resolution screen patent. That is because when Panduit asks about non-infringing alternatives, the only relevant patent is the patent being asserted in the lawsuit. Thus, under the current lost profits test, it is quite possible to find that when a manufacturer infringes two different patents, it is causing two different patentees to lose sales. That means that a given manufacturer may end up paying two lost profits awards. If these awards are not apportioned, the payments would likely drive the manufacturer out of the market.

The Federal Circuit's ruling in Mentor Graphics could also be interpreted as trying to avoid the situation described above by creating a new legal rule that prevents the recognition of more than one "but for" cause. Mentor Graphics said that when a product consists of multiple important patents owned by different parties, "no manufacturer could obtain lost profits on such a [product] (none could satisfy the demand for everything)."178 This may be a new variation of the second Panduit factor, which requires patentees to prove the absence of acceptable non-infringing substitutes. ${ }^{179}$ In practice, this factor limits the infringer's ability to avoid paying lost profits by arguing that customers would have purchased a competing product from a third party. If the third party's products also infringe the patent at issue, they are not a legitimate alternative source, and they cannot prevent a lost profits recovery. In other words, even if true as a factual matter, the law will not allow an infringer to say "but for" the infringement, customers would have chosen a third party's infringing products instead of the patentee's products.

Mentor Graphics takes this analysis and applies it to the patentee. If the patentee's products infringe some third-party patent, they are not a legitimate source for satisfying consumer demand. In other words, Mentor Graphics suggests that even if it is factually true that "but for" the infringement, customers would have purchased the patentee's products, the law should not permit a patentee to make that argument if those products also infringe another's patent.

From a purely doctrinal perspective, this new requirement has no basis in the law. It does not appear that any decision exists that requires a patentee to show that its products do not infringe other patents before it can recover lost profits. As a practical matter, this requirement would be impossible to implement. Patent assertions occur sequentially and many manufacturers do

\footnotetext{
${ }^{178}$ Mentor Graphics, 851 F.3d at 1289.

${ }^{179}$ See Panduit, 575 F.2d at 1156.
} 
not know about numerous important patents. ${ }^{180}$ In fact, patent holders have every reason to lie low. ${ }^{181}$ Thus, when lawsuits like Mentor Graphics go to trial, the parties may not be aware of the other important patents in the field. Moreover, even if they were aware of some of them, injecting third party patents into a patent lawsuit will make trials even more complicated. There will be disputes over whether these third patents are valid and infringed too. Adding this additional layer of complexity to what is already among the most expensive kinds of litigation would be highly undesirable. ${ }^{182}$

\section{Lost Profits Without Apportionment $\approx$ Injunction}

One scholar has argued that it is apportionment, and not "but for" causation damages, that is unfair because apportionment does not make patentees whole. ${ }^{183}$ He points out that if juries were to apportion lost profits, the patentee would only recover a percentage "of the profit it would have made on sales that it would have it made but for [the] infringement." ${ }^{184}$ That would leave the patentee "worse off than it would have been but for the infringement." ${ }^{185}$ Although this fairness critique is factually accurate, keep in mind that the goal of the patent system is not to enrich individual inventors, but to properly incentivize innovation. ${ }^{186}$ When products are made up of a single patented feature, such as some pharmaceutical drugs, weighing competing interests is fairly straightforward. The landscape of modern multicomponent products, however, is far more complex. To simply restore pa-

180 See James Bessen \& Michael J. Meurer, Patent Failure: How Judges, BureauCRATS, AND LAWYERS PUT INNOVATORS AT RISK 71-72 (2008) (describing the difficulty of searching for relevant patents).

${ }^{181}$ See Oskar Liivak, When Nominal Is Reasonable: Damages for the Unpracticed Patent, 56 B.C. L. REV. 1031, 1041 (2015) (noting that the structure of patent law and reasonable royalty rewards incentivizes patenting and waiting to enforce the patent later, rather than innovating); Peter S. Menell \& Michael J. Meurer, Notice Failure and Notice Externalities, 5 J. Legal ANALYSIS 1, 8-9 (2013) (explaining that patent holders have an incentive to hide their patents until after a company has invested heavily in its infringing technology because they are in a more powerful bargaining position); see also Tun-Jen Chiang, The Reciprocity of Search, 66 VAND. L. REV. 1, 13 (2013) (noting that "examples of well-known producers being held up by previously unknown patentees abound").

${ }^{182}$ See Paul R. Gugliuzza, Quick Decisions in Patent Cases, 106 GeO. L.J. (forthcoming 2018) (manuscript at 1) (describing the high cost of patent litigation).

183 Thomas F. Cotter, Comparative Patent Remedies: A Legal and ECONOMic ANALYSIS 115 (2013).

${ }^{184} \mathrm{Id}$.

${ }^{185} \mathrm{Id}$.

${ }^{186}$ Motion Picture Patents Co. v. Universal Film Mfg. Co., 243 U.S. 502, 511 (1917) (“"[T]his court has consistently held that the primary purpose of our patent laws is not the creation of private fortunes for the owners of patents, but is 'to promote the progress of science and useful arts' ...." (quoting U.S. CONST. art. I, § 8)). 
tentees to the place that they would have occupied prior to infringement would impede innovation in these industries.

Unlike in the pharmaceutical industry, modern multicomponent products build on thousands and thousands of other innovations. Thus, it is important for patent law to consider how its rules will affect the kind of complementary innovation that exists in the technology sector. Of course, when inventors use, or infringe, someone else's patent, they still need to pay for the privilege. The remedies, however, should not be so powerful that they would give the patentee control over products that build upon its patent. That is particularly true when that patented feature is simply one of many thousands of different features. Outsized remedies for infringement of such features is what made issuing automatic injunctions to prevailing patentees so problematic prior to eBay. ${ }^{187}$ It effectively allowed a patent on one feature to hold up a multicomponent product.

Although there seems to be a general consensus that patent holdup can be a serious problem, failing to apportion lost profits presents substantially the same issue. When the law grants a permanent injunction against further sales of a product, it effectively gives the patentee control over that product. The patentee can then use the threat of the injunction to insist that the infringer pay all, or nearly all, of the profits that it could make on that product. ${ }^{188}$ Awarding a patentee all of the patentee's lost profits associated with a multicomponent product gives the patentee a remedy of the same magnitude as an injunction. The difference is primarily one of timing. Injunctions allow a patentee leverage to negotiate a disproportionate share of the infringer's future profits. Failing to apportion lost profits awards the patentee a disproportionate share of the infringer's past profits. Indeed, in some cases, failing to apportion lost profits results in a stronger remedy than awarding an injunction. For example, when there is an injunction, the infringer can choose to redesign the infringing feature if those costs are lower than the licensing fee that the patentee demands. In effect, those design costs place an upward bound on the money the patentee can demand with an injunction. When the patentee is awarded lost profits without apportionment, however, it is too late to try to design around the patent. Therefore, the same upward bound does not exist. Regardless of the minor differences between injunctions and unapportioned lost profits, however, the point is the same. For

${ }^{187}$ See supra notes 136-145 and accompanying text (discussing the eBay case).

${ }^{188}$ Lemley \& Shaprio, supra note 138, at 1994-2002 (detailing how the threat of injunction provides negotiating leverage). Although the model looks at negotiating leverage prior to litigation, modifying the chance of prevailing at litigation to $100 \%$ illustrates the leverage a patentee would have with a permanent injunction. 
multicomponent products, they are both outsized remedies that deter innovation.

In short, patent law needs to properly allocate incentives among the many different innovators that contribute to multicomponent products. ${ }^{189}$ Importantly, most infringement does not result from copying, and we should not assign moral blame or punish the infringer in these cases. Most infringement does not result from copying. ${ }^{190}$ Moreover, infringers often add their own contributions. That might take the form of creating unforeseen variations or simply adding new technology. The patent system needs to incentivize those that improve on existing technology. ${ }^{191}$ Apportioning lost profits serves this goal and properly balances incentives for different innovators.

Critics of apportionment rely on the idea of making inventors wholerestoring them to the position that they would have occupied had there been no infringement. The law, however, should not concern itself with making inventors whole at the cost of harming innovation. ${ }^{192}$ Indeed, the Supreme Court has repeatedly made it clear that patent law is focused on the public interest, not individual enrichment. ${ }^{193}$ With that framework in mind, it is clear that patent law's interest in apportioning lost profits is more compelling than concerns about restoring individual inventors to the precise financial status that they would have been in absent infringement.

${ }^{189}$ Chao, The Infringement Continuum, supra note 114, at 1398-1400.

${ }^{190}$ See Christopher A. Cotropia \& Mark A. Lemley, Copying in Patent Law, 87 N.C. L. REv. 1421,1424 (2009) (finding that copying is quite rare in patent litigation). To the extent that there is intentional copying, $\S 284$ of the patent laws provides courts the discretion to award enhanced damages for this kind of intentional conduct. See 35 U.S.C. § 284 (2012); Halo Elecs., Inc. v. Pulse Elecs., Inc., 136 S. Ct. 1923, 1933 (2016).

${ }^{191}$ See Scotchmer, supra note 9, at 30 ("The challenge is to reward early innovators fully for the technological foundation they provide to later innovators, but to reward later innovators adequately for their improvements and new products as well."); see also Landers, supra note 134, at 505 ("The question of incentives must encompass a concern for sequential invention in order to fully conform with the central purpose of the patent system.").

${ }^{192}$ See Sichelman, supra note 6, at 538 (criticizing make-whole remedies as poorly suited for optimizing innovation).

${ }^{193}$ See, e.g., Bilski v. Kappos, 561 U.S. 593, 649 (2010) (Stevens, J., concurring) (expressing concerns about "stiffling] the ... progress" of "scientific and technological work" when discussing patentable subject matter (quoting Gottschalk v. Benson, 409 U.S. 63, 67 (1972))); Quanta Comp., Inc. v. LG Elecs., Inc., 553 U.S. 617, 626 (2008) (discussing the role of patents in "promot[ing] the progress of science and useful arts" when ruling on the proper scope of patent exhaustion (quoting U.S. ConST. art. I, § 8)); Graham v. John Deere Co., 383 U.S. 1, 9 (1966) (asserting that patent law's role was "to bring forth new knowledge" when deciding the standard for obviousness). 


\section{Ordering Effects and Equal Treatment of Licensees}

Yet another problem with refusing to apportion lost profits is that it leads to uneven and inequitable results, with some companies inevitably paying damages that are effectively apportioned, while others do not. This problem stems from the fact that companies learn about patents at different times. If we think about what happens when a third-party patentee licenses a different patented feature to the original patentee and not to the infringer, there are some surprisingly uneven consequences depending on when the license is executed. Consider what would have happened if the third-party patent holder in Mentor Graphics had licensed to Mentor Graphics before it sued Synopsys. ${ }^{194}$ Mentor Graphics' per unit profit would have been smaller, and any lost profits caused by Synopsys' infringement would have been correspondingly smaller. In other words, Synopsys would have had to pay a smaller damages award because Mentor Graphics had taken a license to a third-party patent before the lawsuit. In effect, this is a kind of real world apportionment of lost profits. The infringer, Synopsys, pays a smaller amount in lost profits because some of the profits the patentee would have made are instead channeled to pay another patentee.

The result is different if Mentor Graphics takes the license after its lawsuit with Synopsys. Because Mentor Graphics profits shrink after the lawsuit, those smaller profits cannot be used to reduce the damages Synopsys owes. The information was simply unavailable. The result is that the amount of lost profits damages an infringer like Synopsys pays to a patentee like Mentor Graphics depends on when the patentee takes its licenses to other third-party patent holders. The damages are higher if the patentee can somehow avoid obtaining the licenses it needs until its can recover lost profits damages on its own patents first. The time when a patent holder takes a license to other patented features, however, should have no effect on the damages the patent holder recovers.

This uneven result is caused by the fact that Mentor Graphics awards the lost profits based on the entire product instead of just those attributable with the patented feature. ${ }^{195}$ The same result would not occur if courts apportioned lost profits. Because Mentor Graphics would only recover lost profits attributable to the patented invention and not the entire product, paying royalties on other features would have no effect on Mentor Graphics' recovery, regardless of when those payments took place.

\footnotetext{
${ }^{194}$ See generally Mentor Graphics, 851 F.3d 1275.

${ }^{195} \mathrm{Id}$. at 1290.
} 


\section{CONCLUSION}

This Article presents both doctrinal and policy cases for applying apportionment to lost profits recovery. From a doctrinal perspective, Supreme Court precedent does not support an exclusive "but for" test, but rather a two-step test that includes both "but for" analysis and apportionment. From a policy perspective, it makes no economic sense to award a patentee all of the lost profits associated with an entire product when the patent only covers a single feature. Such a rule overcompensates patentees and wrongly disincentivizes those that would make complementary technologies.

The task of apportionment is not an easy one. The perfect should not, however, be the enemy of the good. As the Supreme Court said long ago about apportioning damages:

It well may be that mathematical exactness [is] not possible, but ... that degree of accuracy is not required but only reasonable approximation, which usually may be attained through the testimony of experts and persons informed by observation and experience. $^{196}$

${ }^{196}$ Dowagiac Mfg. Co. v. Minn. Moline Plow Co., 235 U.S. 641, 647 (1915). 